\title{
Geoprocessing Applied in the Estimate of Infiltration and Surface Runoff in HPP's Contribution Watershed
}

\author{
Elizon Dias Nunes1, Patrícia De Araújo Romão1, Maurício Martines Sales², \\ Marta Pereira Da Luz ${ }^{3,4}$ \\ ${ }^{1}$ Institute of Socio-Environmental Studies, Federal University of Goiás, Goiânia, Brazil \\ ${ }^{2}$ School of Civil and Environmental Engineering, Federal University of Goiás, Goiânia, Brazil \\ ${ }^{3}$ Eletrobras Furnas, Aparecida de Goiânia, Brazil \\ ${ }^{4}$ Polytechnic School, Pontifical Catholic University of Goiás, Goiânia, Brazil \\ Email: elizonnunes@ufg.br,mmartines@ufg.br, patricia_romao@ufg.br, martaluz@furnas.com.br
}

How to cite this paper: Nunes, E.D., Romão, P.D.A., Sales, M.M. and Da Luz, M.P. (2021) Geoprocessing Applied in the Estimate of Infiltration and Surface Runoff in HPP's Contribution Watershed. Journal of Geographic Information System, 13, 643-659.

https://doi.org/10.4236/jgis.2021.136035

Received: October 12, 2021

Accepted: December 5, 2021

Published: December 8, 2021

Copyright $\odot 2021$ by author(s) and Scientific Research Publishing Inc. This work is licensed under the Creative Commons Attribution International License (CC BY 4.0).

http://creativecommons.org/licenses/by/4.0/

\begin{abstract}
The knowledge of the hydrological regime contributes to the prediction of periods of higher or lower water supply as a function of the frequency and volume of rainfall in relation to the pedological, land cover, and land use conditions. This work aims at evaluating the spatio-temporal variability of the infiltration and runoff potential of an area formed by 4 sub-basins tributary to the São Marcos River in Cristalina (GO). The SCS/NRCS-USDA (2004) method was used, using geoprocessing resources, considering soils in dry, semi-humid and humid conditions. The estimates indicate that rainfall with an average of $6.83 \mathrm{~mm}$, in the September-October transition, in the face of soils in the dry condition does not provide surface runoff. Thus, the variability of pedological characteristics associated with the various conditions of coverage and land use indicates that even the areas with lower infiltration potential begin to contribute effectively with their respective channels in the transition from October to November, when rainfall events are more frequent and significant, and the soils are already in conditions of greater humidity.
\end{abstract}

\section{Keywords}

Rainfall Height, Runoff Coefficient, Hydrological Behavior

\section{Introduction}

The knowledge about the hydrological behavior of hydrographic systems allows planning and management, as well as better equating the use of water resources, 
especially in the case of large basins of multiple water use [1]. This assumes greater relevance when it comes to watersheds near large consumer centers, which have high water demand throughout the year. In addition to the ecosystemic functions, we highlight the use of these resources in activities such as navigation, irrigated agriculture, tourism and leisure, public supply and, especially, energy generation [2]. This is a complex but necessary equation; since observing the climatological and hydrological conditions of each area, it seeks to contemplate the most diverse activities, given the importance played by each of them.

The accentuated climatic seasonality prevailing in the Midwest region of Brazil results in a marked asymmetry regarding the distribution and availability of water in river systems, with a notable reflection on the water supply throughout the year [3]. This implies a greater concern about the volume available in the springs and, consequently, about the capacity of surface and subsurface reserves to meet the demands that tend to increase during the dry season. In this sense, it is necessary to evaluate the influence of climate seasonality on the rate of soil wetting in view of the increasing demands for water resources in order to reduce the effect of the asymmetry of rain supply in the behavior of hydrological parameters, especially the contribution of surface and subsurface flows to the flow of water sources [4].

The integration of climatological, geomorphological, pedological, land cover and land use data and variables using models operated in a geoprocessing environment represents one of the major advances in the field of modeling environmental processes and phenomena. In recent decades, the association of mathematics with the advent of computing has resulted in substantial advances in georeferenced spatial data processing technology [5]. By contemplating the spatial and temporal variability of environmental constraints at different scales or levels of detail, these technologies allow the elaboration of true hydrological radiography about the interaction of rainwater with soil and terrain properties. Consequently, they enable a dynamic approach to the behavior of infiltration and runoff [6]. Thus, based on the behavior of the spatial variability of the conditioning factors, it is possible to establish zoning proposals in which it is possible to ensure patterns of hydrological behavior and, consequently, work with greater predictability of water supply.

The relationships involving rainfall, soil infiltration and runoff on the ground are very complex because besides not being fully amenable to direct observations in the field, they vary according to the conditions of each environment [7] [8]. However, the analysis of the continuous distribution of the main variables and their correlation with the behavior of the processes directly monitored in the field and under specific environmental conditions, allows representative models to be developed and applied with reasonable levels of precision and accuracy [9] [10]. Among these models, the $\mathrm{CN}$ (Curve Number) method proposed by the SCS (Soil Conservation Service), currently NRCS-USDA (Natural Resources Conservation Service-United States Department of Agriculture), stands out, which since 1954 has undergone several improvements and with wide applica- 
tion in several countries [11]. With this, it has become a widely used model as it is based on the amount of rainfall resulting from a given rainfall event, the infiltration capacity of soils and losses resulting from local environmental factors such as microrelief, as well as other losses of lesser impact, having presented good results in applications in Brazil [12].

Thus, diagnoses resulting from hydrological studies constitute the starting point for the definition of mitigating or mitigating actions, insofar as they allow the identification of the factors that condition critical situations and, consequently, locate the environments in which such situations predominate. In environments where rainfall supply tends to be scarce or of markedly asymmetric distribution, a better understanding of the hydrological functions performed by soils in relation to the storage capacity and maintenance of the perenniality of springs and drainage channels is necessary, even in periods of drought [13] [14]. Thus, the integrated assessment of hydrological parameters in areas of direct influence of reservoirs, whatever their use, allows, for example, greater predictability of hydrological conditions, which provides more efficient management of surface water resources, observing the existing dependence between rainfall regime and behavior of water in contact with the soil [15].

In this sense, the present work aims to evaluate the spatial and temporal variability of the behavior of the hydrological parameters infiltration potential, effective precipitation and runoff under rainfall conditions representative of the pre-rainy season, beginning of the rainy season and full rainy season in the contribution areas of the right bank basins of the São Marcos River in the municipality of Cristalina, state of Goiás, Brazil. The knowledge about the spatial and temporal variability of the behavior of these parameters is of great importance for a better understanding of the relationship between rainfall occurrence and volume and the response time in reservoir level rise. This relationship operated by geoprocessing resources provides a greater quantity of calculations and, consequently, greater spatial and temporal detailing of the results. This provides a more detailed understanding of the interdependence of conditioning factors, especially rainfall intensity and duration, permeability and porosity of soils, the influence of relief and land cover and use on the hydrological balance.

\section{Location and Characterization of the Study Area}

The study area comprises 4 sub-basins on the right bank of the São Marcos River in the municipality of Cristalina, state of Goiás, Brazil, and that drain directly into the reservoir of HPP Batalha-FURNAS, as shown in Figure 1. It comprises an area with the predominance of agriculture, especially irrigated, with emphasis on the high number of irrigation pivots [16]. The higher and flatter parts are supported by detrital-lateritic ferruginous covers composed of clusters of laterites, clay and sand. The intermediate and steeper portions are developed over the Canastra Group-Paracatu Formation with the predominance of sericite and carbonaceous phyllite. This transition to the lower parts with the occurrence of 


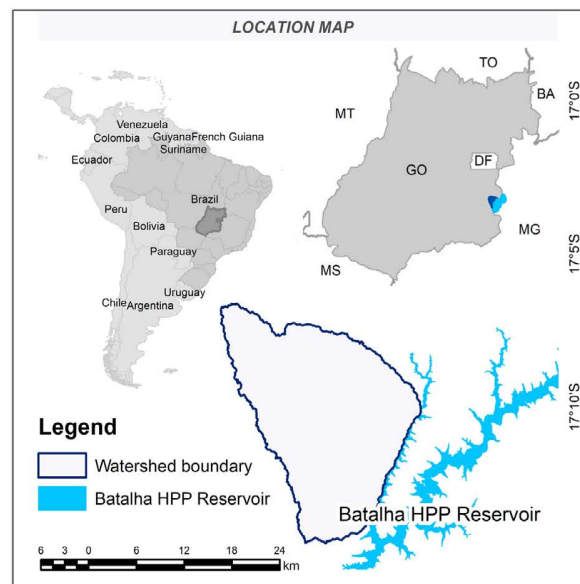

(a)

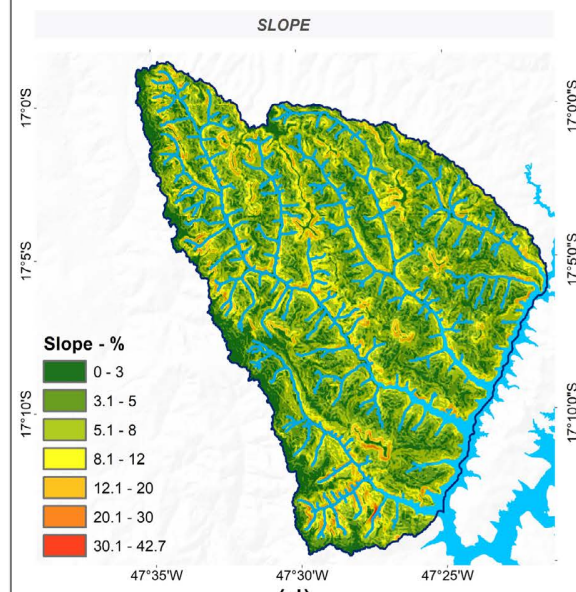

(d)

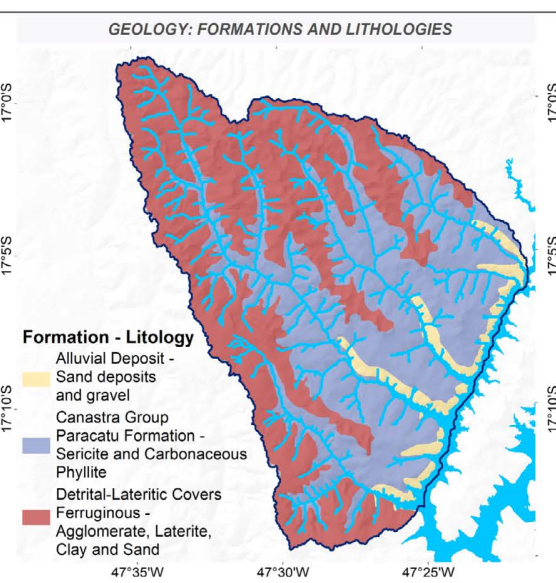

(b)

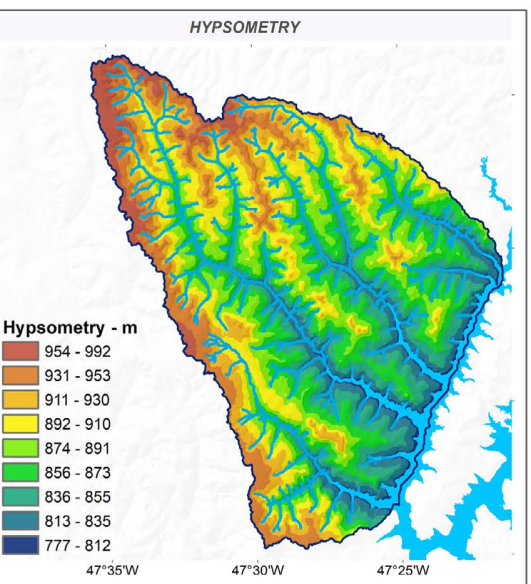

(c)

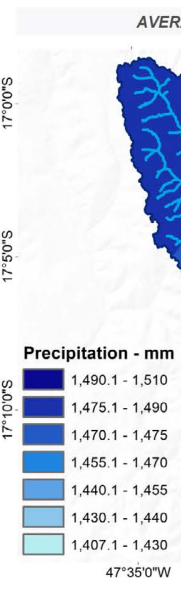

$47^{\circ} 35^{\circ} \mathrm{O}^{\mathrm{W}} \mathrm{W}$

AVERAGE ANNUAL PRECIPITATION

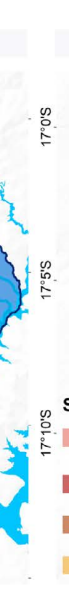

(e)

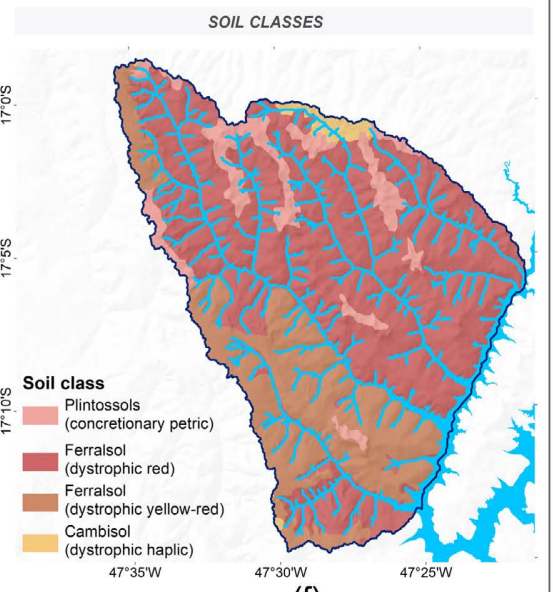

(f)

Figure 1. (a)-(f): (a) Location map; (b) geology-formation and predominant lithologies; (c) hypsometry; (d) slope; (e) precipitation; and (f) soils. Source: Prepared by the authors.

Alluvial Deposits composed of sand and gravel [17]. Considering the World Reference Base for Soil Resources [18], in the higher and residual parts the Plintossols (Petric) predominates, followed by lower and flatter areas with the predominance of Ferralsol (Red), sometimes (Yellow-Red), followed by steeper segments with the association of Cambisol (Haplic) and Leptsol, ending in long plains with low altimetric gradient with the predominance of Fluvisol and Gleysol (Haplic) [19] [20]. The climate of the area can be characterized as tropical semi-humid with dry winter, precipitation of 5.3 to $6.9 \mathrm{~mm}$ in the months of June and July respectively, and temperature of $24.6^{\circ} \mathrm{C}$ in June. The summer is hot and rainy with accumulated precipitation ranging from $243.1 \mathrm{~mm}$ to 275.2 $\mathrm{mm}$ in the months of January and December respectively, and temperature around $30.3^{\circ} \mathrm{C}$ in the month of October [21] [22].

\section{Methodology}

The methodology consisted in evaluating the effects resulting from the occurrence of rainfall events in view of the conditions of relief, soil type, cover and 
use, as well as antecedent moisture conditions (AMC) in the spatial variability of the estimates of infiltration potential, effective precipitation and peak flow. For this purpose, the approach occurred at the slope scale contemplating the specific contribution area to its respective drainage channel. For the pre rainy season situation (AMC I), the soil was considered to be in the dry condition where the accumulated rainfall in the last 5 days is $<13 \mathrm{~mm}$. For the following period, beginning of the rainy period and of greater regularity of rainfall (AMC II) the soil was considered in the intermediate condition in which the accumulated rainfall in the last 5 days is $\geq 13$ and $\leq$ than $53 \mathrm{~mm}$. For the full rainy period (AMC III) the soil was considered to be in a humid condition or close to saturation where the accumulated rainfall in the last 5 days is $>53 \mathrm{~mm}$.

\subsection{Spatial Variability of Effective Precipitation Estimates}

The effective precipitation was determined based on the proposal of the Soil Conservation Service (SCS), now Natural Resources Conservation Service (NRCS) of the U. S. Department of Agriculture, with its first version published in 1954 [23]. This proposal has undergone several revisions, one of them in 1993, and has been widely applied, including by the Federal Highway Administration (FHA-U.S. Department of Transportation) [24], consisting of the ratio between the rainfall resulting from the rainfall event and the infiltration capacity of soils, as presented in Equation (1).

$$
P e=\left[\frac{(P-0.2 S)^{2}}{(P+0.8 S)}\right], \text { when } P \geq I a=0.2 S .
$$

where: $P e=$ effective precipitation, or resulting water sheet height, in $\mathrm{mm} ; P=$ precipitation or rainfall height resulting from a given event, in $\mathrm{mm}$; $S=$ soil infiltration potential, in $\mathrm{mm}$; and $I a=0.2 S$ abstraction or initial loss considered.

As observed in the first part of Equation (1), in the effective precipitation an initial loss corresponding to $20 \%$ of the infiltration potential is considered, due to interception by vegetation, retention in micro relief, as well as other forms of wetting of the surface environment. This implies that rainfall events with total volume less than $20 \%$ of the soil infiltration potential do not provide surface runoff.

\subsection{Estimation of Intensity, Duration, and Accumulated Rainfall Volume}

The values of total precipitation accumulated in the rainfall event in each of the three seasonal situations considered were determined by analyzing the average values of precipitation over the last 15 years from the meteorological station code A036 operated by the National Institute of Meteorology in the municipality of Cristalina-GO. For the condition preceding the beginning of the rainy season, the precipitation was determined based on the average of rainfall events that occurred in late September and early October, which are around $6.83 \mathrm{~mm}$. For the beginning of the rainy season and more regular rainfall, the rainfall was determined based on the average of rainfall events in the second half of October, 
which were around $22.83 \mathrm{~mm}$. For the rainy season, the rainfall height was determined by means of the relationship Intensity-Duration-Frequency (IDF) [25], using Equation (2) [26] for the city of Cristalina.

$$
i=\frac{K \times T R^{a}}{(t+b)^{c}} \Rightarrow i=\frac{878.213 \times T R^{0.2088}}{(t+12)^{0.7600}}
$$

where: $i=$ average of maximum rainfall intensities, in $\mathrm{mm} / \mathrm{h} ; T=$ return time considered, in years; $t=$ time of concentration, in min; and $K, a, b$ and $c$ adjustment coefficients specific to the climatological station.

For this purpose, the rainfall time was considered equal to the longest runoff concentration time found in the basins. The rainfall height resulted from the product of the precipitation intensity and the duration of the rain. Since this is not a study related to safety works, a return time of 25 years was considered in the present proposal.

For the concentration time we used the relationship between flow or basin length and average slope [27] using Equation (3).

$$
T C=7.68\left(L / S w^{0.5}\right)^{0.79}
$$

where: $T c=$ runoff concentration time, in min; $L w=$ length of the basin main flow line, in $\mathrm{km}$; and $S=$ average basin slope in $\mathrm{m} / \mathrm{m}$.

\subsection{Determination of Runoff Number (CN) and Infiltration Potential (S)}

The $\mathrm{S}$ values were estimated based on the $\mathrm{CN}$ (runoff number) values, according to the Natural Resources Conservation Service (NRCS-USDA) [23], as presented in Equation (4).

$$
S=\frac{25400}{\mathrm{CN}}-254
$$

where: $S=$ infiltration potential, in $\mathrm{mm} ; \mathrm{CN}=$ Curve Number, dimensionless; and 25,400 and 254 are constants originating from the model.

For this purpose, the $\mathrm{CN}$ values were determined based on the evaluation of soil types-especially texture and depth-and its classification into Hydrological Groups (HG) as presented in Table 1 [28] [29] the conditions of cover and use and the antecedent humidity. In this method, the $\mathrm{CN}$ values vary from 0 (low flow capacity) to 100 (high flow capacity). It is noteworthy that for this calculation the soil was considered in three conditions of antecedent moisture: 1) the situation preceding the beginning of the rainy period with the soil in the dry condition (5-day precipitation $<13 \mathrm{~mm}=$ AMC I);2) the one corresponding to the beginning of the rainy period and greater rainfall regularity, with the soil in the intermediate condition ( $13 \mathrm{~mm} \leq 5$-day precipitation $\leq 53 \mathrm{~mm}=\mathrm{AMC} \mathrm{II})$; and 3) referring to the full rainy period, with the soil in the wet condition (5-day precipitation $>53 \mathrm{~mm}=$ AMC III).

An example of the association of land cover classes and land use conditions with the Hydrologic Groups and their resulting runoff number values can be 
Table 1. Soil classes, texture and their correspondence in hydrological groups.

\begin{tabular}{ccc}
\hline Soil Class & Texture & $\begin{array}{c}\text { Hydrological } \\
\text { Group }\end{array}$ \\
\hline Gleysol (Dystrophic Haplic) & Clayey & A \\
Fluvisol (Dystrophic) & Mean to Sandy & A \\
Ferralsol (Dystrophic Red) & Very Clayey to Clayey & B \\
Ferralsol (Dystrophic Yellow-Red) & Clayey & B \\
Cambisol (Dystrophic Haplic) & Clayey to Mean & C \\
Plintossol (Concretionary Petric) & Clayey to Gravel & C \\
Leptsol (Dystrophic) & Sandy to Gravel & D \\
\hline
\end{tabular}

Source: adapted by the authors from [19] [20].

Table 2. Land cover and land use types and conditions, relationship with hydrologic groups, and respective curve number values at AMC II.

\begin{tabular}{ccccc}
\hline & \multicolumn{5}{c}{ Hydrological Group } \\
\cline { 2 - 5 } Coverage and use classes & A & B & C & D \\
\hline Agriculture-level terracing & 60 & 71 & 79 & 82 \\
Bare ground-with conservation & 62 & 71 & 78 & 81 \\
Bare ground-no conservation & 72 & 81 & 88 & 91 \\
Pasture-medium and low transpiration & 47 & 67 & 81 & 88 \\
Reforestation-medium transpiration & 36 & 60 & 70 & 76 \\
Forests-dense and high transpiration & 26 & 52 & 62 & 69 \\
Savannas-medium transpiration & 36 & 60 & 73 & 79 \\
$\begin{array}{c}\text { Permanent grasslands-dense coverage } \\
\text { and high-transpiration }\end{array}$ & 25 & 55 & 70 & 77 \\
$\begin{array}{c}\text { Permanent grasslands-dense coverage } \\
\text { and mean transpiration }\end{array}$ & 36 & 60 & 73 & 79 \\
\hline
\end{tabular}

Source: Prepared by the authors from the multi-spectral Instrument (MSI) sensor of the Sentinel-2 satellite, with passage on June 8, 2020 and adapted from [28] [29].

seen in Table 2 [28] [29].

The conversion of Curve Number values from the normal or intermediate moisture condition to the dry and wet soil conditions was done using Equations (5) and (6), respectively [23]:

$$
\begin{aligned}
& \mathrm{CN} \mathrm{I}=4.2 \times \mathrm{CN} \mathrm{II} / 10-0.058 \times \mathrm{CN} \text { II } \\
& \mathrm{CN} \mathrm{III}=23 \times \mathrm{CN} \mathrm{II} / 10+0.13 \times \mathrm{CN} \text { II }
\end{aligned}
$$

\subsection{Estimation of Runoff Concentration Time and Peak Flows}

The peak flow rate was determined as proposed in Equation (7) [30].

$$
q p=0.0021 \times Q \times A / T p
$$


where: $q p=$ peak event flow rate, in $\mathrm{m}^{3} / \mathrm{s} ; Q=$ effective precipitation or portion of precipitation available for surface runoff, in $\mathrm{mm} ; A=$ contribution area, in ha; and $T p=$ peak time of the hydrograph, in hour. In applying this equation, a peak time corresponding to 0.6 of the concentration time of each basin was considered through Equation (8) [31].

$$
T p=0.6 \times T c
$$

\section{Results and Discussion}

\subsection{Flow Length, Concentration Time and Contribution Area}

Considering the approach of the four basins in specific contributing areas and at the strand scale for their respective drainage channels, it can be seen that the flow lines along the strand can reach up to $2227 \mathrm{~m}$. This length results in a runoff concentration time of up to 46.9 minutes, with the more distant and flatter areas naturally taking longer to contribute flow to the drainage channels. As for the specific contribution area, it ranged from 0.09 , at the top of the interfluves, to 145.45 ha at the connection points with the drainage channels. As can be observed from Figure 2, the four higher-order basins tend to present an elongated

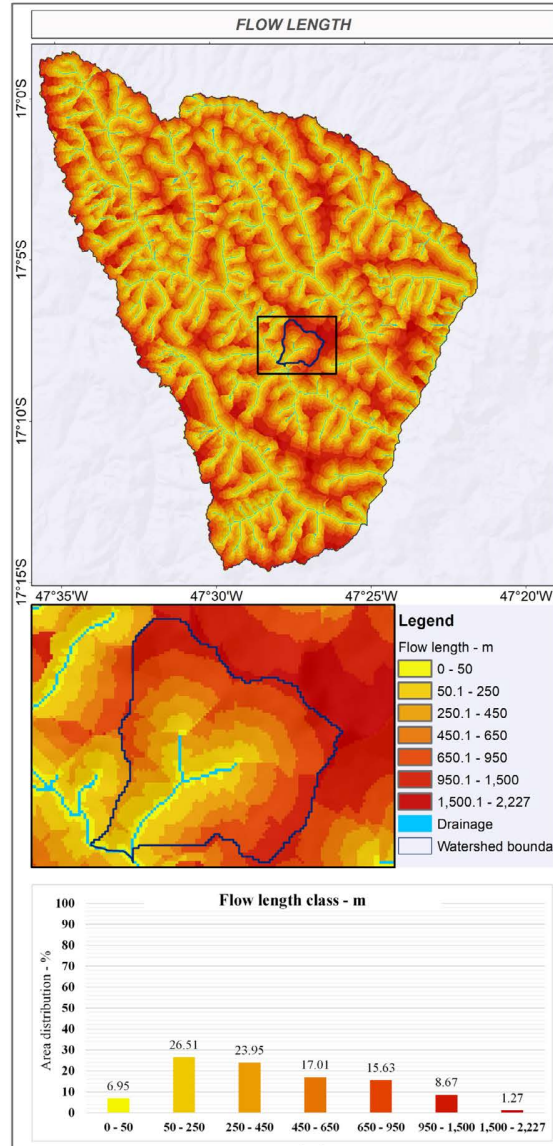

(a)

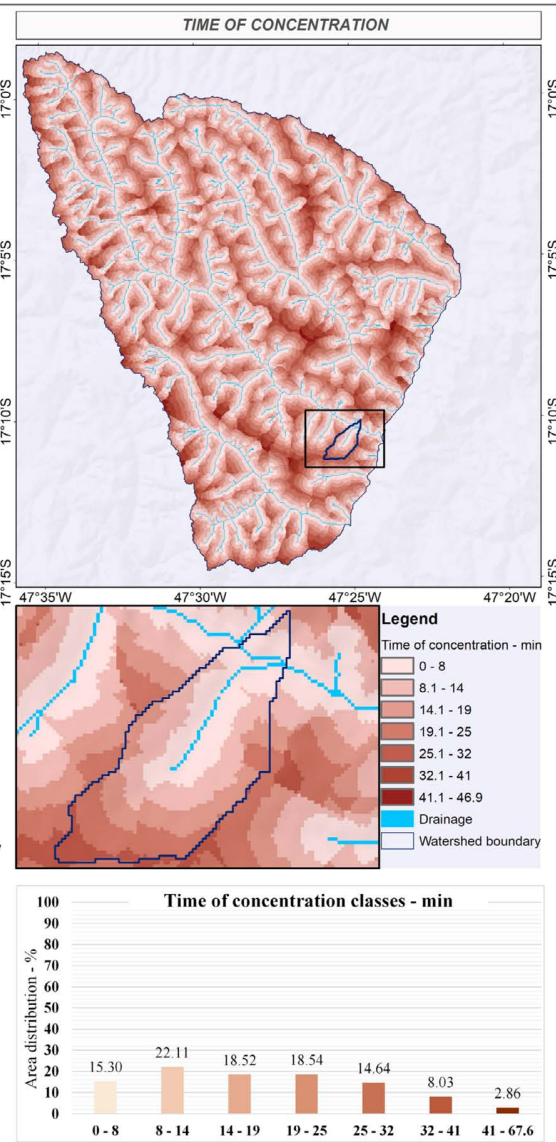

(b)

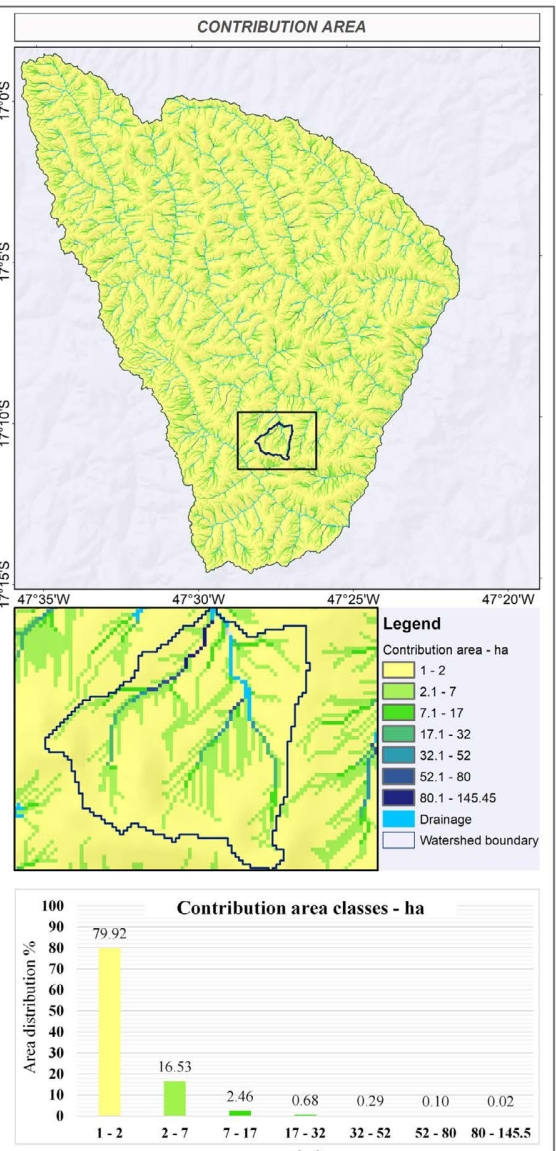

(c)

Figure 2. (a)-(c): Flow length (part a); Time of concentration (part b); Contribution area (part c). In detail, example of the behavior of each parameter, in specific contribution areas, on a strand scale. Source: Prepared by the authors. 
pattern, in contrast to the basins of the smaller tributaries, which present a more symmetrical radial pattern, configuring a more homogeneous morphometry. Relating the length of the strand with the length of the channels, it can be seen that the channels are up to 15 times more extensive than the flows lines developed along the strand.

A direct consequence of this behavior is the tendency of simultaneous contribution of the area of the lower order basins to their respective channels. However, considering the elongated character of the higher order basins, the influence of the hydrologic effects resulting from each sub-basin tends to occur in a gradual way [32]. These characteristics, associated with the low altimetric gradient along the main channels, confer to these basins low probability of occurrence of peak flows or overload in the main channels [33] [34]. Consequently, the high morphometric asymmetry between the contribution area at the slope level and the area of the higher-order basins suggests the need for long-lasting and higher-volume rainfall events so that rainfall can contribute, via hydrographic subsystems, to the reservoir.

The relief is distributed in three main altimetric levels, with slopes ranging from $0 \%$ to $8 \%$, which transition from plateaus to pediments and from these to plains, by means of amphitheaters. The highest slopes occur in the transition zones between surfaces, which are small and rarely range between $20 \%$ and $43 \%$. Although in the transition between one plateau and another slopes that can reach $43 \%$ predominate, these are of little occurrence and the effects resulting from the high runoff coefficients developed upstream tend to be attenuated by the high infiltration potentials prevailing along the plains.

\subsection{Rainfall Height, Hydrologic Groups, Cover and Use Conditions, and Behavior of Hydrologic Parameters}

Taking as a reference the adopted methodology, the average precipitation of rainfall events that precede the rainy season, as well as the association of hydrological groups with the various conditions of land use, it can be seen that the predominant rainfall at the end of September and beginning of October is not sufficient to produce runoff. As observed in Figure 3, considering an average precipitation of $6.83 \mathrm{~mm}$ per rainfall event, one cannot envision scenarios of effective precipitation, nor of occurrence of surface runoff along the area of each of the four sub-basins under analysis.

Under these conditions, it can be seen that the curve number values varied from 0 to 81, with a strong predominance of values between 40 and 60 resulting from the association of clayey textured Ferralsol on flat relief and used for agriculture, indicating low humidity and high infiltration capacity. Values between 60 and 70 occur more isolated on steep slopes, located between residual hills and flatter terrain or between the edges of larger interfluves and river plains, resulting from the association of poorly developed soils, such as Cambisols and Leptsol, associated with savanna and grassland vegetation. Consequently, for the 


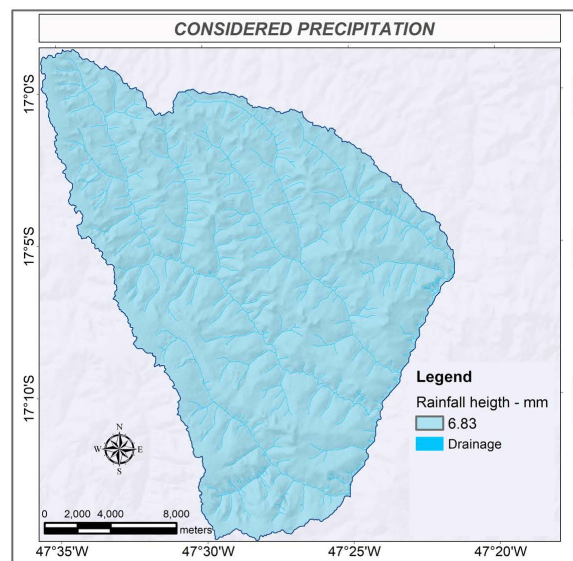

(a)

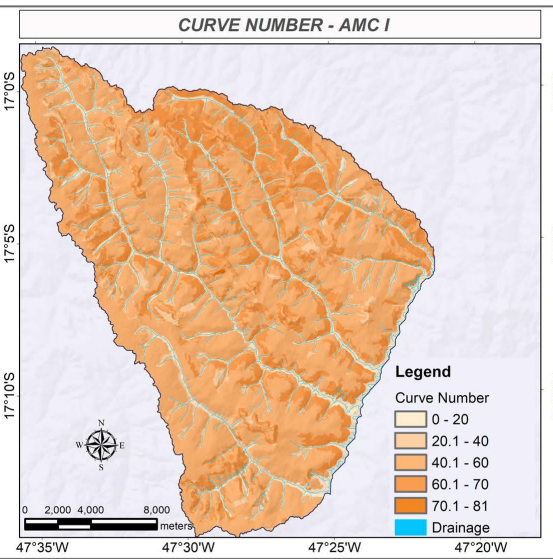

(b)

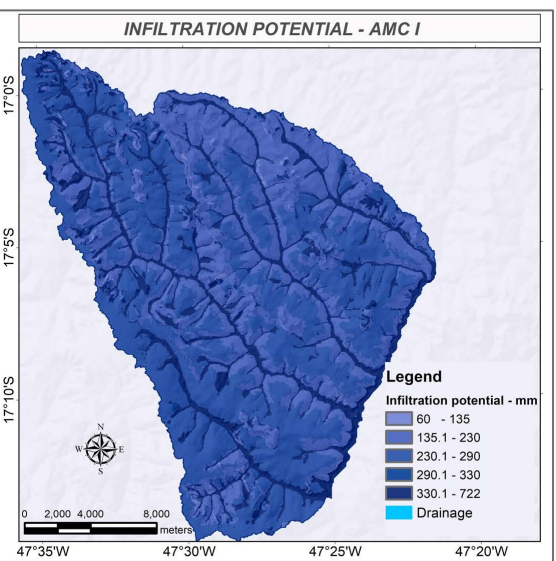

(c)

Figure 3. (a)-(c): Considered precipitation (part a); runoff number (part b); infiltration potential (part c) in the dry antecedent moisture condition (5-day precipitation $<13 \mathrm{~mm}$ ). Source: Prepared by the authors.

above mentioned antecedent humidity condition, one can notice along the basins a strong predominance of the $135-230 \mathrm{~mm}$ infiltration potential classes and, mainly, of 230 to $290 \mathrm{~mm}$ in extensive areas, being that in some areas the infiltration potential can reach $722 \mathrm{~mm}$. These result from the occurrence of Fluvisol of sandy texture, sometimes overlying soils of the type Gleysol of clayey texture, associated with low altimetric gradient plains and with the occurrence of dense vegetation. From the above, it is understood that these rainfall conditions in view of the pedological, morphometric and soil cover and use characteristics, result in contributions only to the gradual gain of soil moisture, without direct surface contribution to water bodies, especially to adjacent reservoirs.

Throughout Figure 4 it is possible to quantitatively observe values that corroborate the tendency to low curve number and the strong predisposition of large percentages of areas with high infiltration potentials. In this condition, it is worth noting that almost the totality of the area has infiltration potential above $135 \mathrm{~mm}$, with the class larger than $330 \mathrm{~mm}$ covering about $17 \%$ of the whole area.

For the situation of greater rainfall regularity, predominant in the second half of October, it can be seen that the supply of rain associated with the antecedent soil moisture is already likely to generate surface runoff and the consequent contribution to the respective drainage channels. In this sense, considering an average rainfall of $22.83 \mathrm{~mm}$ in each rainfall event and the soil in the intermediate condition of antecedent humidity, a sharp increase in the range of classes of higher number of runoff can be noticed. Thus, the extreme values went from 80 in the dry condition, to 91 in the intermediate condition. In this same sense, the most notable is the predominance of the class ranging from 70.1 to 80 , which now predominates in about $79 \%$ of the area, where previously the class from 60.1 to 70 prevailed. Under these conditions, there is a noticeable reduction in the infiltration capacity of water into the soil, whose predominant class becomes that varying from 60 to $135 \mathrm{~mm}$, as shown in Figures 5(a)-(f). 
AREA DISTRIBUTION OF CURVE NUMBER CLASSES AND INFILTRATION POTENTIAL IN AMC I

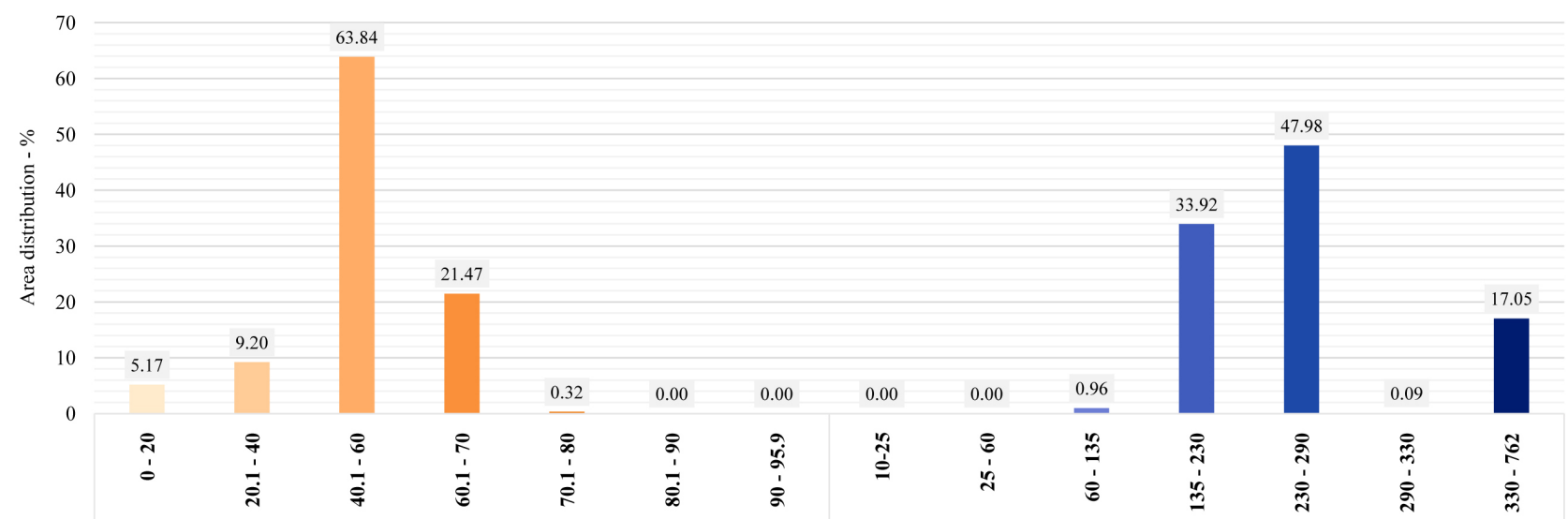

Curve Number

Infiltration Potential - mm

Figure 4. Graph of the relative distribution of area in curve number classes and in Infiltration potential classes in the dry antecedent moisture condition (5-day precipitation $<13 \mathrm{~mm}$ ). Source: Prepared by the authors.

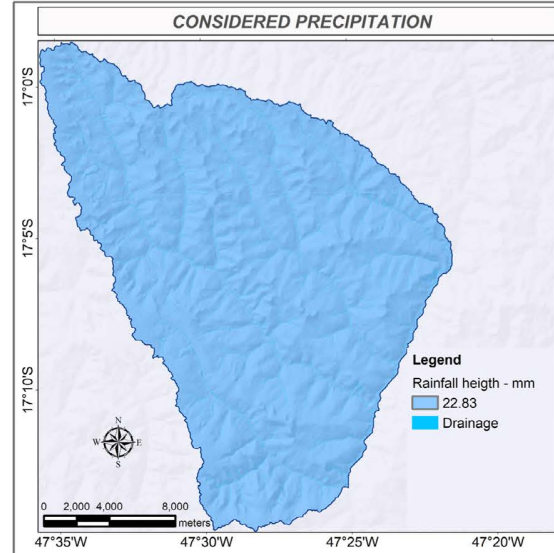

(a)

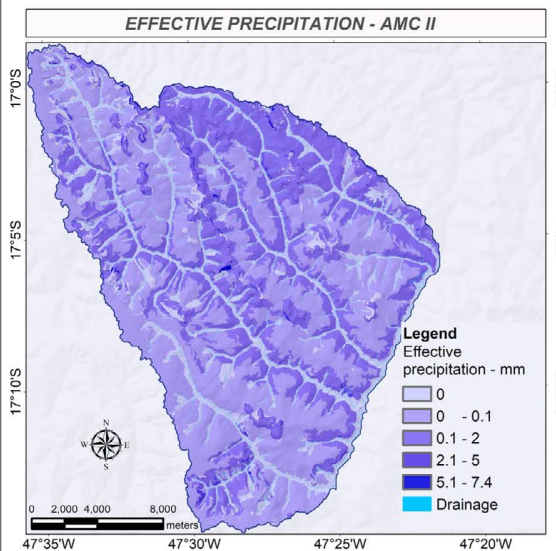

(d)

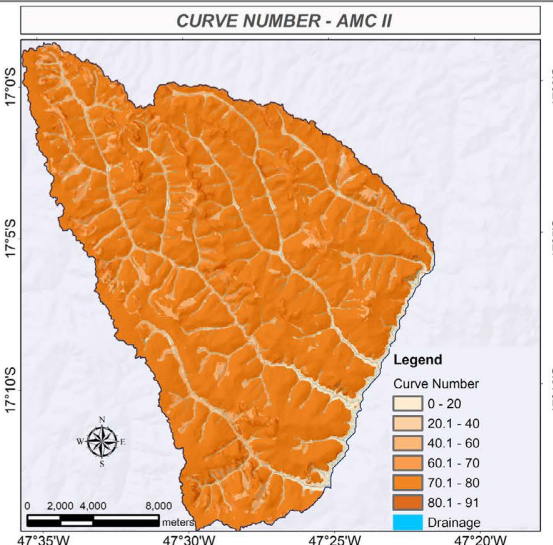

(b)

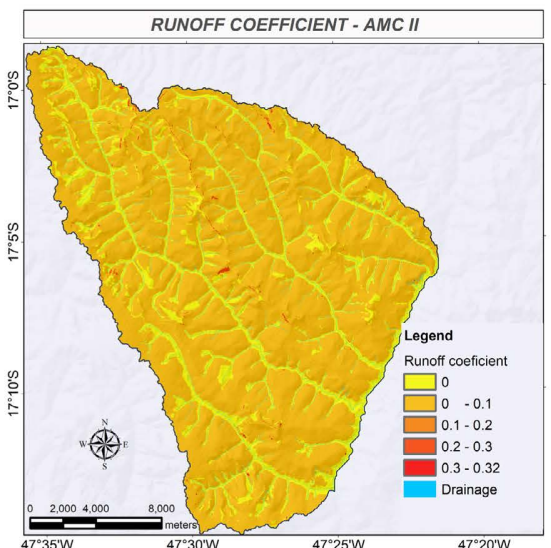

(e)

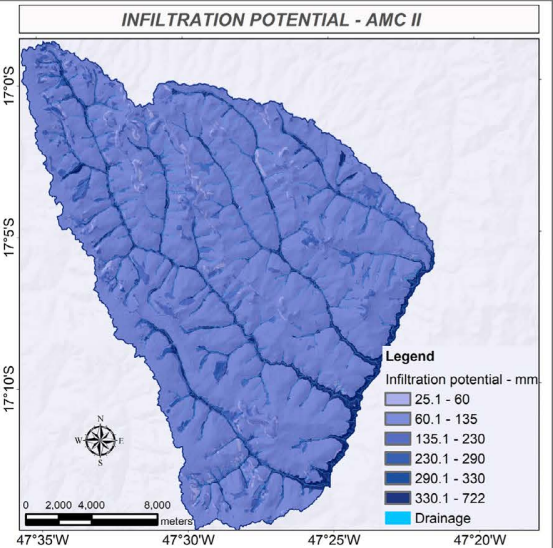

(c)

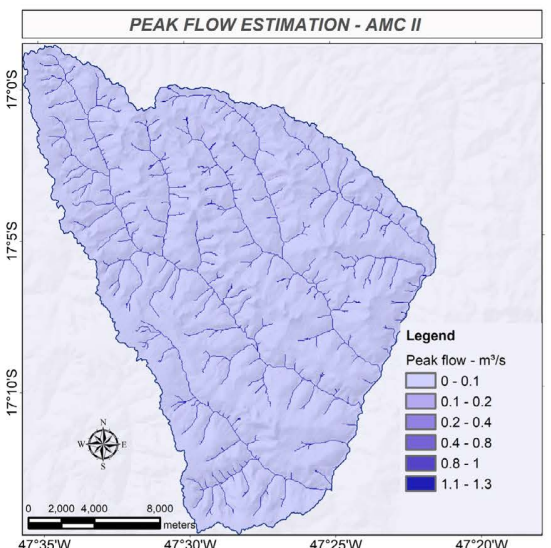

(f)

Figure 5. (a)-(f): Considered precipitation (part a); curve number (part b); infiltration potential (part c); effective precipitation (part d); runoff coefficient (part e); and flow peak estimation (part $\mathrm{f}$ ) in the intermediate antecedent moisture condition (13 mm $\leq$ 5 days precipitation $\leq 53 \mathrm{~mm}$ ). Source: Prepared by the authors. 
In these conditions it is already possible to verify the occurrence of effective precipitation with a height of up to $7.4 \mathrm{~mm}$, especially in the steeper areas and less developed soils, such as Cambisol and, mainly, Leptsol, both with low infiltration potential. As for the area corresponding to the fluvial plain, the effective precipitation is null due to the topographic, pedologic and cover and use conditions, unfavorable to the formation of surface runoff. Similar behavior can be verified for surface runoff estimates, which already reach values up to 0.3 in the steepest areas, with the predominance of litholic neosols. In these conditions of effective precipitation and runoff coefficients above zero, it is also possible to notice the occurrence of surface runoff, whose convergence in areas with high specific contribution, reaches flow peaks of up to $1.3 \mathrm{~m}^{3} / \mathrm{s}$.

Likewise, along Figure 6 it is possible to obtain a quantitative summary of the hydrological parameters previously mentioned. Also noteworthy are the occurrence of areas corresponding to the high runoff number classes; the tendency of low infiltration capacity of the soils; the consequent occurrence of effective precipitation; the occurrence of surface runoff above zero; and, mainly, the occurrence of peak flows of up to $1.3 \mathrm{~m}^{3} / \mathrm{s}$, notably in the convergence segments of the slope flow, in the headwaters of the drainage channels.

In the rainy season and considering the soil in the humid condition, the maximum value of the runoff number went from 91 to 95.9 , with the class from 80.1 to 90 becoming predominant in approximately $81.7 \%$ of the area. Under these conditions there is also a tendency for a generalized reduction in the infiltration potential, with a greater predominance of the class ranging from 25 to 60 $\mathrm{mm}$. Even so, even under conditions of high antecedent humidity, a high infiltration potential is verified, especially along the plains of the main drainage channels. This finding corroborates the influence of the association of alluvial and hydromorphic soils, sometimes deep, developed along wide plains of low altimetric gradient and mostly covered by forests, such as gallery and riparian forests, with high infiltration potential.

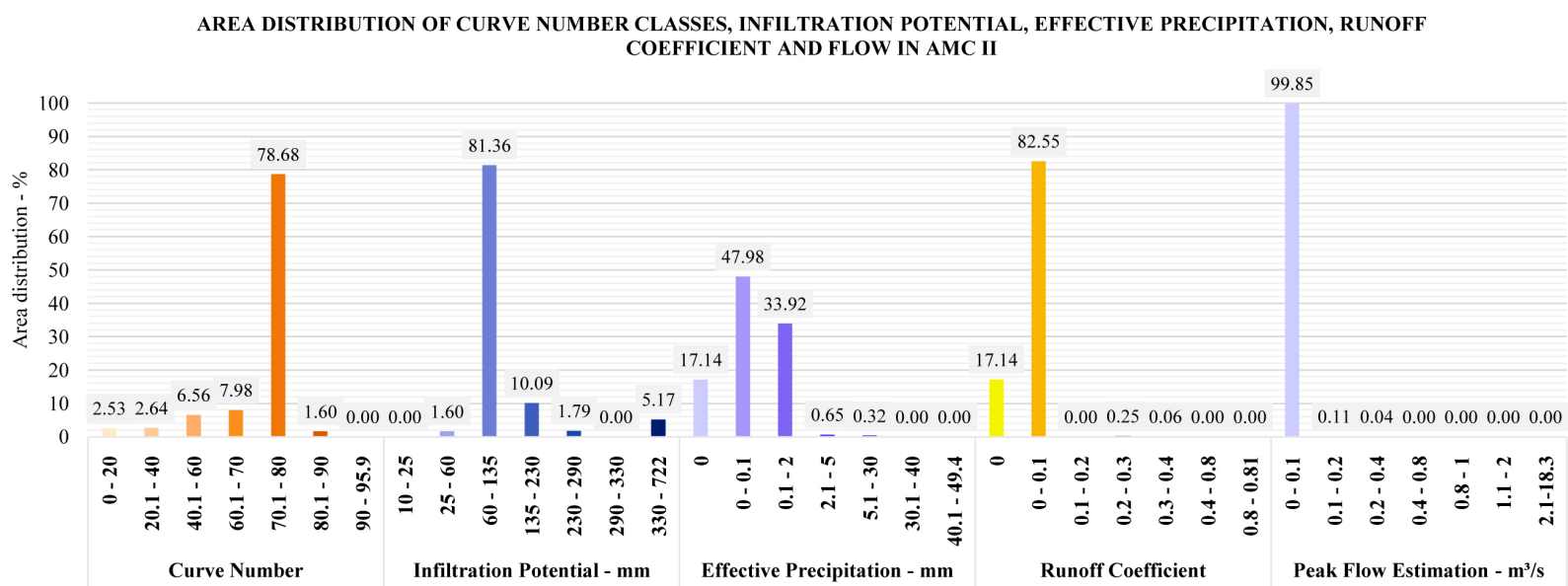

Figure 6. Graph of the relative distribution of the area in classes of curve number; infiltration potential, effective precipitation, surface runoff coefficient and flow estimation in the intermediate antecedent moisture condition ( $13 \mathrm{~mm} \leq 5$ days precipitation $\leq$ $53 \mathrm{~mm})$. Source: Prepared by the authors. 


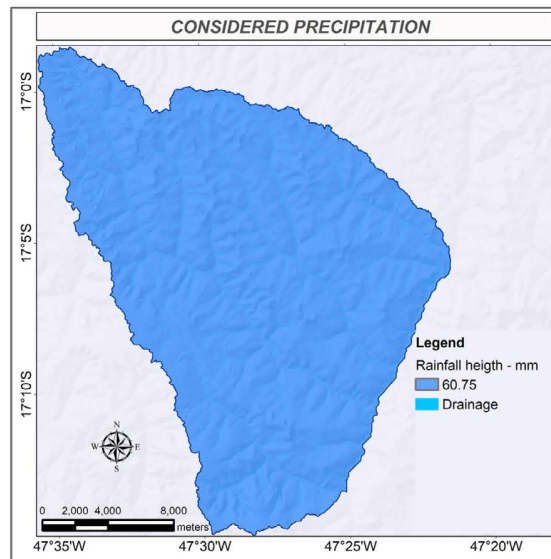

(a)

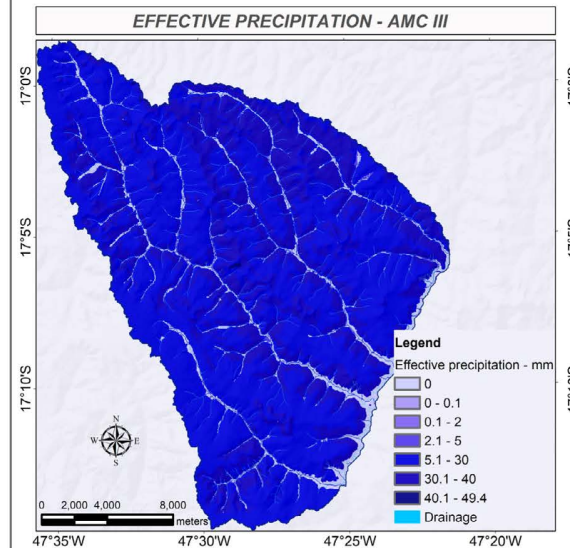

(d)

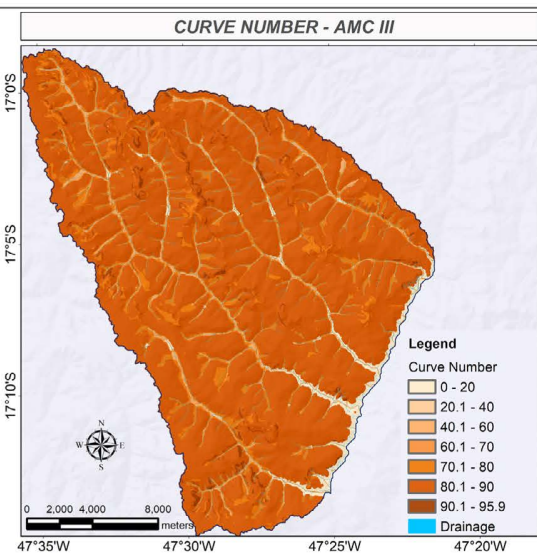

(b)

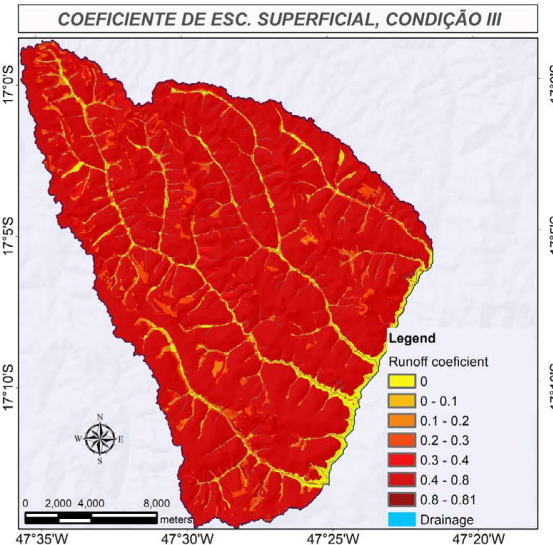

(e)

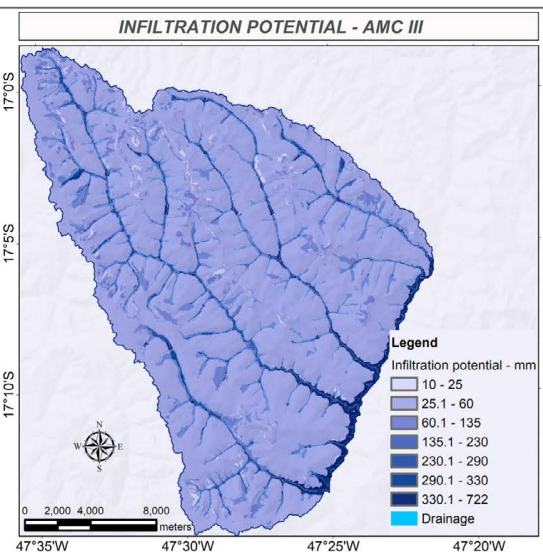

(c)

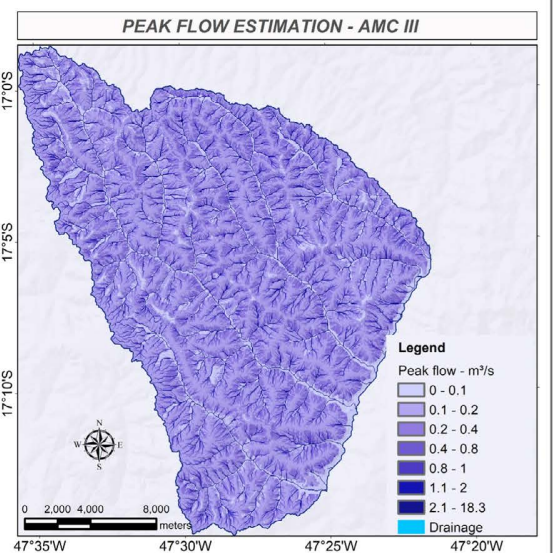

(f)

Figure 7. Considered precipitation (part a); curve number (part b); infiltration potential (part c); effective precipitation (part d); runoff coefficient (part e); and estimated flow (part $\mathrm{f}$ ) in the wet condition (5-day precipitation $>53 \mathrm{~mm}$ ). Source: Prepared by the authors.

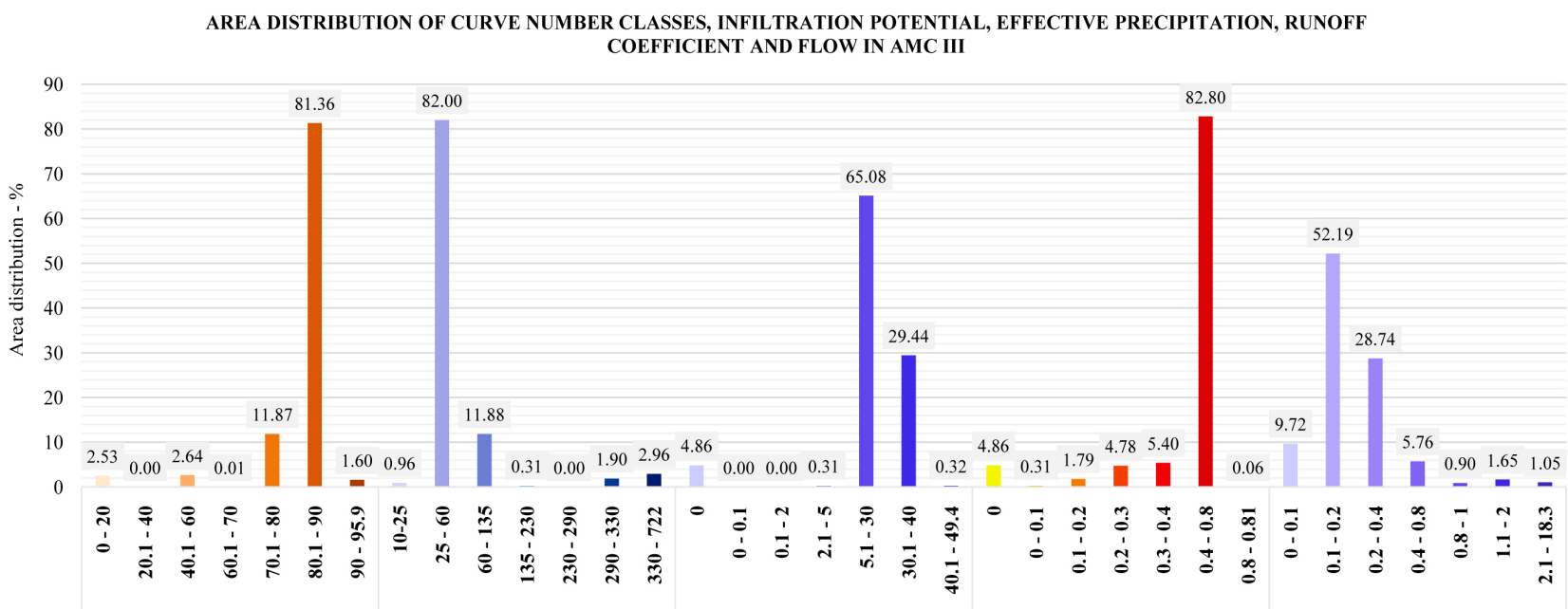

Curve Number

Infiltration Potential - mm

Effective Precipitation - mm

Runoff Coefficient

Peak Flow Estimation - $\mathrm{m}^{3 / \mathrm{s}}$

Figure 8. Graph of the relative area distribution in classes of curve number; infiltration potential, effective precipitation, surface runoff coefficient, and flow estimation in the wet condition (5-day precipitation > $53 \mathrm{~mm}$ ). Source: Prepared by the authors. 
In this situation and considering a rainfall time of 46.88 minutes, under an intensity of $77.68 \mathrm{~mm} / \mathrm{h}$, resulting in a rainfall height of $60.69 \mathrm{~mm}$ and the soil in the humid condition, the potential of the specific contribution areas to the drainage channels proved to be more satisfactory. The effective precipitation now tends to reach values of up to $49.4 \mathrm{~mm}$, notably in the steeper areas, with the predominance of poorly developed soils. As a great highlight, we highlight the strong predominance of the classes ranging from 5.1 to $30 \mathrm{~mm}$ and 30 to $40 \mathrm{~mm}$, which, when facing situations of flow convergence and soils with low infiltration capacity, tend to result in higher peak flows. Such tendency is reaffirmed in situations of high runoff coefficient, especially for classes varying from 0.4 to 0.8 , as observed along Figure 7 and Figure 8.

\section{Conclusions}

The morphometric and pedological conditions related to soil cover, use, and management, suggest hydrographic systems with high hydrological potential, as well as considerable travel time, especially for the four higher-order channels. This potential is conditioned by the predominance of extensive areas of flat relief associated with soils with reasonable depth and texture varying from clayey to very clayey and with use predominantly by agriculture in level terrace systems. These conditions act to keep the surface runoff at low velocities and, consequently, provide more time for concentration, which is essential to the infiltration process.

With reference to the evaluation of the set of hydrological variables, it is concluded that the area of the sub-basins on the right bank of the São Marcos River constitutes an area with high hydrological potential, even in humid soil conditions. This fact can be corroborated when one associates the elongated format of the higher-order basins with their long and wide fluvial plains that aggregate a high infiltration potential, even in the rainy season. If considered the response time of hydrological conditioning and its contribution to the increase in reservoir volume, this implies more time for the rainy season to contribute more effectively to the reservoir. However, this high infiltration capacity in most of the basins contributes to the postponement of the effects of droughts on the flow of drainage channels, as long as the existing dams along them release the minimum background flow.

This work is the beginning of a series of initiatives aimed at better understanding the relationship between the rainfall regime and the behavior of reservoir levels. In this sense, we highlight the need for advances in the methodological proposal, using field data for validation that are representative of the variability of hydrological conditions for the entire reservoir contribution watershed and in greater temporal detail. These adjustments are essential for the structuring of a Geographic Information System applied to the spatial-temporal monitoring of hydrological conditions throughout the basin and its relationship with the behavior of the reservoir level. 


\section{Acknowledgements}

This work is part of the Research \& Development project "Modeling at Different Scales of Sediment Generation in Erosion and Sediment Delivery in UHEs Reservoirs"-PD-0394-1705/2017, regulated by the National Agency of Electric Energy-ANEEL-BRAZIL, developed by Eletrobras FURNAS and the Federal University of Goiás and the University of Brasilia.

\section{Conflicts of Interest}

The authors declare no conflicts of interest regarding the publication of this paper.

\section{References}

[1] Rocha, P.C. and Santos, A.A. (2018) Análise hidrológica em bacias hidrográficas. Mercator, 17, 1-18. https://doi.org/10.4215/rm2018.e17025

[2] Yu, Y., Loiskandl, W., Kaul, H.-P., Himmelbauer, M., Wei, W., Chen, L. and Bodner, G. (2016) Estimation of Runoff Mitigation by Morphologically Different Cover Crop Root Systems. Journal of Hydrology, 538, 667-676.

https://doi.org/10.1016/j.jhydrol.2016.04.060

[3] Luiz, G.C. and Romão, P.A. (2020) Interação solo-atmosfera e processos de inundação e alagamentos na cidade de Goiânia-GO. Revista Brasileira de Geografia Física, 12, 1891-1903. https://doi.org/10.26848/rbgf.v12.5.p1891-1903

[4] Andrade, E.M., Rodrigues, R.N., Palácio, H.A.Q., Brasil, J.B. and Filho, J.C.R. (2018) Hydrological Responses of a Watershed to Vegetation Changes in a Tropical Semiarid Region. Revista Caatinga, 31, 161-170. https://doi.org/10.26848/rbgf.v12.5.p1891-1903

[5] Liu, J., Liu, S., Tieszen, L.L. and Chen, M. (2007) Estimating Soil Erosion Using the USPED Model and Consecutive Remotely Sensed Land Cover Observations. In: Proceedings of the 2007 Summer Computer Simulation Conference-SCSC, ACM, San Diego, Vol. 16, 1-6.

[6] Viana, J.F.S., Montenegro, S.M.G.L., Silva, B.B., Silva, R.M. and Sousa, W.S. (2018) Modelagem hidrológica da bacia hidrográfica do rio Pirapama-PE utilizando o modelo SWAT. Journal of Environmental Analysis and Progress, 3, 155-172. https://doi.org/10.24221/jeap.3.1.2018.1709.155-172

[7] Ahmad, I., Verma, V. and Verma, M.K. (2015) Application of Curve Number Method for Estimation of Runoff Potential in GIS Environment. In: II International Conference on Geological and Civil Engineering-IPCBEE, IACSIT Press, Singapore, Vol. 80, 16-20.

[8] Mamédio, F.M.P., Castro, N.M.R. and Corseiul, C.W. (2018) Tempo de concentração para bacias rurais monitoradas na Região do Planalto Basáltico no Sul do Brasil. Revista de Gestão de Água da América Latina, 15, 1-17. https://doi.org/10.21168/rega.v15e1

[9] Mitasova, H., Barton, M., Ullah, I., Hofierka, J. and Harmon, R.S. (2013) GIS-Based Soil Erosion modeling. In: Shroder, J., Ed., Treatise on Geomorfology, Academic Press, San Diego, 228-258. https://doi.org/10.1016/B978-0-12-374739-6.00052-X

[10] Harmon, B.A., Mitasova, H., Petrosova, A. and Petras, V. (2019) S.sim.terrain 1.0: A Landscapes Evolution Model with Dynamic Hydrology. Geoscientific Model Development, 12, 2837-2854. https://doi.org/10.5194/gmd-12-2837-2019 
[11] Meshram, S.G., Sharma, S.K. and Tignath, S. (2017) Application of Remote Sensing and Geographical Information System for Generation of Runoff Curve Number. Applied Water Science, 7, 1773-1779. https://doi.org/10.1007/s13201-015-0350-7

[12] Soares, M.R.G.J., Fiori, C.O., Silveira, C.T. and Kaviski, E. (2017) Eficiência do método Curve Number de retenção de águas pluviais. Mercator, 16, 1-16.

[13] Souza, J.O.P. and Corrêa, A.C.B. (2019) Escoamento superficial e balanço hídrico em ambientes secos com topografia complexa-bacia do Riacho do Saco-PE. Geographia, 21, 106-119. https://doi.org/10.22409/GEOgraphia2019.v21i46.a14159

[14] Andrade, E.M., Rodrigues, R.N., Palácio, H.A.Q., Brasil, J.B. and Guerreiro, M.J.S. (2020) Hydrological Behavior of Vertisols in the Brazilian Semiarid Region: The Importance of Rainfall of Less than 30 mm. Revista Ciência Agronômica, 51, 1-10. https://doi.org/10.5935/1806-6690.20200029

[15] Rodrigues, S.S.R., Bittencourt, G.M. and Fernandes, L.L. (2018) Escoamento superficial em uma pequena bacia hidrográfica rural da Amazônia. Revista Brasileira de Cartografia, 70, 605-628. https://doi.org/10.14393/rbcv70n2-45400

[16] Pereira Júnior, L.C.P., Ferreira, N.C. and Miziara, F.A. (2017) Expansão da irrigação por pivôs centrais no estado de Goiás (1984-2015). Boletim Goiano de Geografia, 37, 323-341. https://doi.org/10.5216/bgg.v37i2.49158

[17] Moreira, M.L.O., Moreton, L.C., Araújo, V.A., Lacerda Filho, J.V. and Costa, H.F. (2008) Geologia do estado de Goiás e Distrito Federal: Texto explicativo do mapa geológico do estado de Goiás e Distrito Federal. CPRM; SIC-FUNMINERAL, Goiânia, 143 p. http://www2.sieg.go.gov.br/post/ver/169639/publicacoes:-geoprocessamento

[18] IUSS Working Group WRB (2015) World Reference Base for Soil Resources 2014, Update 2015 International Soil Classification System for Naming Soils and Creating Legends for Soil Maps. World Soil Resources Reports, 106, FAO, Rome, 203 p. http://www.fao.org/3/i3794en/I3794en.pdf

[19] Resende, M.J.G. (2016) Classes de solos dos municípios goianos-2016. EMATER, Goiânia, 57 p.

https://www.docsity.com/pt/tipos-de-solos-e-solos-tropicais/4971350/

[20] Rosa, L.E., Santos, N.B.F., Bayer, M., Castro, S.S., Nunes, E.D. and Cherem, L.F.S. (2018) Atributos para mapeamento digital de solos: O estudo de caso na bacia do ribeirão Arrojado, município de Cristalina-Goiás. In: Oliveira, A.C., Ed., Elementos da natureza e propriedades do solo, Atena Editora, Ponta Grossa, 68-82.

[21] Monteiro, C.A.F. (1951) Notas para o estudo do clima do Centro-Oeste. Brasileiro. Revista Brasileira de Geografia, 13, 3-46.

https://biblioteca.ibge.gov.br/visualizacao/monografias/GEBIS\%20-\%20RJ/RBG/RB G\%201951\%20v13_n1.pdf

[22] Novais, G.T. (2020) Climate Classification Applied to the State of Goiás and the Federal District, Brazil. Boletim Goiano de Geografia, 40, 1-29.

https://www.revistas.ufg.br/bgg/article/view/62297

[23] NRCS-National Resources Conservation Service (2004) Chapter 10. Estimation of Direct Runoff from Storm Rainfall. In: National Engineering Handbook, USDADepartment of Agriculture, Washington DC, $79 \mathrm{p}$. https://directives.sc.egov.usda.gov/OpenNonWebContent.aspx? content=17752.wba

[24] FHA-Federal Highway Administration (2013) Urban Drainage Design Manual. Hydraulic Engineering, Circular 22, 3rd Edition, USDT-National Highway Institute, Washington DC, $478 \mathrm{p}$. https://www.fhwa.dot.gov/engineering/hydraulics/pubs/10009/10009.pdf

[25] Villela, S.M. and Mattos, A. (1975) Hidrologia Aplicada. McGrawHill do Brasil 
Ltda., São Paulo, 245 p.

[26] Oliveira, L.F.C., Cortês, F.C., Wehr, T.R., Borges, L.B., Sarmento, P.H.L. and Griebeler, N.P. (2005) Intensidade-Duração-Frequência de chuvas intensas para localidades no estado de Goiás e Distrito Federal. Pesquisa Agropecuária Tropical, 35, 13-18. https://www.revistas.ufg.br/pat/article/view/2277

[27] Watt, W.E. and Chow, K.C.A. (1985) A General Expression for Basin Lag Time. Canadian Journal of Civil Engineering, 12, 294-300. https://doi.org/10.1139/185-031

[28] Tucci, C.E.M. (2008) Águas urbanas. Estudos Avançados, 22, 97-112. https://www.revistas.usp.br/eav/article/view/10295 https://doi.org/10.1590/S0103-40142008000200007

[29] Tucci, C.E.M. and Marques, D.M.L.M. (2001) Avaliação e controle da drenagem urbana. UFRGS, Porto Alegre, $558 \mathrm{p}$.

[30] Schwab, G.O., Fangmeier, D.D., Elliot, W.J. and Frevert, R.K. (1993) Soil and Water Conservation Engineering. John Wiley \& Sons, Chichester, 528 p.

[31] Gray, D.M. (1973) Handbook on the Principles of Hydrology. Water Information Center Incorporated, Minnesota, $591 \mathrm{p}$.

[32] Horton, R.E. (1945) Erosional Development of Streams and Their Drainage Basins: Hydrophysical Approach to Quantitative Morphology. Geological Society of America Bulletin, 56, 275-370. https://doi.org/10.1130/0016-7606(1945)56[275:EDOSAT]2.0.CO;2

[33] Alves, J.M.P. and Castro, P.T.A. (2003) Influência de feições geológicas na morfologia da bacia do rio Tanque (MG) baseada no estudo de parâmetros morfométricos e análise de padrões de lineamentos. Revista Brasileira de Geociências, 33, 117-127. https://doi.org/10.25249/0375-7536.2003332117124

[34] Santos, C.L., Silva, O.G., Vital, S.R.O. and Wanderley, L.S.A. (2018) Análise da suscetibilidade à ocorrência de enchentes e inundações na bacia do rio Jaguaribe-João Pessoa/PB. Revista Brasileira de Geografia Física, 11, 1876-1888.

https://doi.org/10.26848/rbgf.v11.5.p1876-1888 